\title{
The Age-Divide in E-Government - Data, Interpretations, Theory Fragments
}

\author{
Björn Niehaves, Jörg Becker \\ European Research Center for Information Systems, University of Muenster, \\ Leonardo-Campus 3, 48149 Muenster, Germany, \\ \{Becker, Bjoern.Niehaves\}@ercis.uni-muenster.de
}

\begin{abstract}
. 14 of the world's 15 'oldest' countries (largest percentage of people age 65 plus) are to be found in Europe. While E-Government is currently establishing as the most important public sector reform strategy in the EU (Lisbon Agenda), age is a factor which strongly affects EGovernment usage. Under the label of 'E-Inclusion' EU policies seeks to solve also age-related digital divide issues. This paper seeks to explore the age-divide in E-Government and discusses 2006 Eurostat data on online service usage. The case of Germany will be given as example.
\end{abstract}

\section{Introduction}

Population aging is one of the greatest challenges to societies in Europe! Some claim it is a sign of the success of Western societies: as medicine, sanitation, and agricultural production have improved, life expectancy has risen. This, combined with plunging birth rates, is causing what is called the 'demographic transition'. One of the biggest impacts of this transition is population aging. Europe has seen both mortality and fertility fall since the 19th century. Since the 1960s, however, fertility has declined even more dramatically. Europe now has so many elderly people and so few newborns that, as a consequence, population aging has established itself as a longterm trend that will continue for generations to come. Today, 14 -besides Japan- of the world's 15 'oldest' countries - those with the largest percentage of elderly people (age 65 or older) - are in Europe. In Italy, Europe's oldest country by these standards, around $19.5 \%$ of the population is elderly. In other European countries, including Germany, Greece, Sweden, Bulgaria, Belgium, and Portugal, the percentage of elderly is over $17 \%$. In Spain, Estonia, Latvia, Croatia, France, UK, and Finland their

Please use the following format when citing this chapter:

Niehaves, B., Becker, J., 2008, in IFIP International Federation for Information Processing, Volume 286; Towards Sustainable Society on Ubiquitous Networks, eds. Oya, M., Uda, R., Yasunobu, C., (Boston: Springer), pp. 279-287. 
share is larger than $16 \%$ (Population Reference Bureau, 2006). Population aging is not only a challenge in Europe, but it is indeed a European Challenge.

While E-Government is establishing as the most important public sector reform strategy, age is a factor which strongly affects E-Government usage! A key element of public sector reforms in the EU (European Union) is E-Government (Electronic Government) which can be defined as the use of information technology in governments. In the move of the Lisbon-Agenda, all EU member states have committed to implementing an E-Government-oriented strategy of public administration modernisation. Web-based information and communication technologies are intended to become the primary channel for public service delivery. According to the European Commission, in 2004 an average of $84 \%$ of all public services was available online in the EU member states. Despite such positive efforts to provide E-Government services, analyses of usage numbers and user structures indicate that digital exclusion today is primarily a demand side rather than a supply side issue. Here, especially senior citizens are still potentially very much excluded from participation in electronic services.

Against this background, the aim of this paper is to investigate into the digital divide in E-Government taking into account the specific perspective of senior citizens. Here, we seek to develop complexity of age-aware E-Government rather than to reduce complexity in terms of, for instance, an age-aware Technology Acceptance Model for E-Government. Thus, the research method chosen is that of a descriptivestatistical analysis followed by a comprehensive interpretation. Such interpretive discussion is aimed at contributing to a foundation of a preliminary theory of age-aware E-Government. Therefore, we will contrast different types of online service usage data, including general internet usage, E-Commerce usage as well as E-Government usage. Taking the exemplary case of Germany, we seek to address the research question of "What is the current state of inclusive E-Government, especially from the perspective of senior citizens, and which factors could explain a possible inclusion gap to which extent?"

In order to address this research question, the following section will relate our analysis to prior studies and the existing literature. Section 3 presents the research methodology, focusing on a quantitative analysis of comprehensive Eurostat data from digital divide group perspectives. Following a comparative presentation and discussion of relevant data, a comprehensive data interpretation seeks to offer explanations for inclusion gaps in (German) E-Government and identify potential operational strategies to overcome a digital divide in E-Government (Section 4). The paper will conclude with a summary of results and an outlook to potentially fruitful avenues for future research (Section 5). 


\section{Related Work}

\subsection{Demographic Transition}

According to Hauser \& Duncan (1959), demography can be defined as ,the study of the size, territorial distribution, and composition of population, changes therein, and the components of such changes, which may be identified as natality, mortality, territorial movement (migration), and social mobility (change of status)“ (p.2). Here, literature identifies three specifically major factors underlying to the development of demography: a) fertility, b) mortality, and c) migrations (Kaufmann 2005). Accordingly, demographic transition can be understood as the progressive alteration of these determinants. Especially fertility and mortality have undergone significant changes in most industrialized countries. On the one hand, fertility has been declining due to, for instance, changed life models or family planning and the possibilities of birth control and abortion (Hill and Kopp 2000). Morgan \& Hagewen (2005) state that fertility transitions "[...] are complete in many developed countries and are in progress in much of the rest of the world. The transition model has three stages: relatively high and stable fertility, followed by a period of fertility decline, and then followed by relatively low and stable fertility (p. 231). While life expectancy is rising and populating experiences normal aging, less young people are succeeding which results in an overall aging of the society in these countries. The old-age dependency ratio that sets the number of people aged over 60 years in relation to the number of people aged between 20 and 60 years dramatically increased by two to three times its size in some industrialized countries (Birg 2005). Therefore, societal aging can be identified as a major element of demographic transition in industrialized countries (Niehaves et al. 2008).

\subsection{E-Inclusion}

These trends pose several challenges to the development of E-Government strategies. One of these challenges is the digital divide, in this context understood as an emerging polarization phenomenon in society, creating a gap between those who do have access to and use the potentialities of information and communication technologies, and those who do not (European Commission 2004a). The demographic gap refers, amongst others, to the fact that senior people often do not use ICT on a regular basis (E-Aging, Becker et al. 2008). The reasons for this gap results from a multitude of several challenges which senior people often face. These include for instance isolation, physical disabilities, or low retirement pension (Kraner 2004). Disabilities can debar people from actively using information technology. For the usage of online services the most important disabilities to consider are visual handicaps, cognitive defects and limitations of motor skills. Geographical differences refer to gaps in ICT usage between different regions. Socio-economic gaps include differences in occupa- 
tion, income and education whereas ethnical and cultural gaps identify barriers in the ICT usage of migrants and ethnical minorities.

Here, E-Inclusion focuses on the elimination of these barriers for the use of ICT. The declaration of Riga gives the following definition of E-Inclusion: "'eInclusion' means both inclusive ICT and the use of ICT to achieve wider inclusion objectives. It focuses on participation of all individuals and communities in all aspects of the information society. eInclusion policy, therefore, aims at reducing gaps in ICT usage and promoting the use of ICT to overcome exclusion, and improve economic performance, employment opportunities, quality of life, social participation and cohesion." (European Union 2006, p. 1) The main focus of E-Inclusion is on creating accessible services over ICT. This effort can be divided into accessibility and usability aspects (Kraner 2004). Accessibility means the possibility for handicapped people to access the relevant service. This includes for instance creating opportunities for Braille support on web-sites and general thoughts about compatibility with older technologies. Usability focuses on the user-friendliness of a web-service. According to EU's "Top of the web" report, the main criteria for this effort includes easy discovery and fast navigation within a website, easy use of the service, satisfying speed and a clear language that is easy to understand (European Commission 2004b).

\subsection{Effects of Aging}

Aging is certainly one of the most important aspects to consider when creating or adapting E-Government strategies. According to Davis' Technology Acceptance Model (TAM), the two main dimensions of technology acceptance are perceived usefulness and perceived ease of use (Davis et al. 1989). The perceived usefulness on the one hand has the biggest influence on the actual usage. Older people are lacking the awareness of advantages related to ICT usage because they are easily satisfied with their current possibilities and cannot imagine how ICT could improve their lives (Morris and Venkatesh 2000). They have a critical attitude towards the usage of new technologies because they did not get used to them throughout their working lives. They appreciate the face-to-face contact and fear that new media will contribute to their isolation. The perceived ease of use, on the other hand, is usually declining with an increasing age. An impairment of vision implies difficulties in recognizing details especially if they are presented on a computer screen (Shirley 2004). Furthermore, it is harder for the elderly to adapt necessary skills because they have problems to understand complex new processes. A recent study showed that especially older people feel "more often than the others that the work pace, things to be remembered, rules to be taken into consideration, difficulty of tasks, and monitoring of their work had increased" (European Commission, p. 98).

Against this discussion, it is to investigate into the question of if age is a factor which in a certain way specifically affects E-Government usage or if age generally affects all types of online service usage in a similar way. In order to analyse the potential specific effects of age on E-Government usage, we will contrast internet and ECommerce usage with E-Government usage both from the perspective of the total population and the group of senior citizens. 


\section{Research Methodology}

In order to answer the research question and populate the model, a descriptivestatistical quantitative analysis of Eurostat data from 2006 (Eurostat 2007) on individual internet-based service usage was conducted. A methodological description of the survey is given by the European Commission (European Commission 2006). While such data is secondary data and publicly available, a specific investigation into the in- and exclusiveness in European, and specifically German E-Government has not yet been undertaken. Consequently, the analysis of such comprehensive and high quality and comprehensive data (sample size: $n=21.160$ ) offers great potential to shed new light on the question of the status-quo of inclusive E-Government and on the question of which factors could explain possible inclusion gaps. Table 1 shows questions used to collect the data for the different variables.

Table 1. (Individual) Usage of Internet, E-Commerce, E-Banking, and E-Government and Corresponding Questions.

\begin{tabular}{ll}
\hline Analysis Dimension & Question \\
\hline Internet & I have used the Internet in the last 3 months \\
E-Commerce & $\begin{array}{l}\text { I bought or ordered goods or services, over the Internet, for } \\
\text { non-work use, in the last 3 months }\end{array}$ \\
E-Government & $\begin{array}{l}\text { I have used Internet, in the last } 3 \text { months, for obtaining in- } \\
\text { formation from public authorities web sites }\end{array}$ \\
\hline
\end{tabular}

Moreover, in order to allow for a deeper analysis of non-usage of E-Government services, reasons for non-usage (on an individual basis) are taken into account and range from non-availability of services over concerns about data security, privacy or costs to complexity of (electronic) public services (see Table 2). These two analysis dimensions (usage data and reasons for non-usage) are contrastively discussed taking into account the population average and the group of senior citizens (within the Eurostat data defined of age 55-74). 
Table 2. (Individual) Reasons for Non-Usage of E-Government and Corresponding Questions.

\begin{tabular}{|c|c|}
\hline Reason & Question \\
\hline $\begin{array}{l}\text { Service not available / to } \\
\text { difficult to find }\end{array}$ & $\begin{array}{l}\text { I'm not using Internet for dealing with public services or } \\
\text { administrations, because: The services I need are not avail- } \\
\text { able on-line or difficult to find }\end{array}$ \\
\hline Personal contact missed & $\begin{array}{l}\text { I'm not using Internet for dealing with public services or } \\
\text { administrations, because: I miss personal contact }\end{array}$ \\
\hline $\begin{array}{l}\text { Immediate response } \\
\text { missed }\end{array}$ & $\begin{array}{l}\text { I'm not using Internet for dealing with public services or } \\
\text { administrations, because: I miss immediate response }\end{array}$ \\
\hline $\begin{array}{l}\text { Concerned about data se- } \\
\text { curity }\end{array}$ & $\begin{array}{l}\text { I'm not using Internet for dealing with public services or } \\
\text { administrations, because: I'm concerned about protection } \\
\text { and security of my data }\end{array}$ \\
\hline $\begin{array}{l}\text { Concerned about addi- } \\
\text { tional costs }\end{array}$ & $\begin{array}{l}\text { I'm not using Internet for dealing with public services or } \\
\text { administrations, because: I'm concerned about additional } \\
\text { costs }\end{array}$ \\
\hline Too complex & $\begin{array}{l}\text { I'm not using Internet for dealing with public services or } \\
\text { administrations, because: it's too complex }\end{array}$ \\
\hline Other reasons & $\begin{array}{l}\text { I'm not using Internet for dealing with public services or } \\
\text { administrations, because of other reasons }\end{array}$ \\
\hline
\end{tabular}

\section{The Age-Divide in E-Government}

Analysing in- and exclusiveness of electronic public service delivery in Germany, data on internet, E-Commerce, and E-Government usage was contrasted (see Table 3). While $69 \%$ the total population used the internet during the last three months, only $37 \%$ of senior citizens did so. In the total population, a gap of $10 \%$ can be identified between E-Commerce (38\%) and E-Government (28\%) usage. This gap is significantly smaller regarding the group of senior citizens which used E-Commerce in $15 \%$ and E-Government in $12 \%$ of the cases.

Table 3. Usage Data of Online Services in Germany

\begin{tabular}{lcc}
\hline & Total population & Senior Citizens (Age 55-74) \\
Internet & $69 \%$ & $37 \%$ \\
E-Commerce & $38 \%$ & $15 \%$ \\
E-Government & $28 \%$ & $12 \%$ \\
\hline
\end{tabular}

In addition, the E-Commerce and E-Government usage was seen in relation to only the onliners in the total population and in the group of senior citizens. In the total population, $55.1 \%$ of onliners used E-Commerce and $41 \%$ of onliners used EGovernment. In the group of senior citizens, $40.5 \%$ of onliners used E-Commerce and $32.4 \%$ used E-Government. Relating these two service-specific figure between the total population and senior citizens shows that even if a senior citizen is already online, the probability that she or he uses E-Commerce or E-Government Services is still lower than in the total population (0.74 resp. 0.79; see table 4$)$. 
Table 4. eService Usage Ratio of Senior Onliners \& Total Population Onliners (Germany).

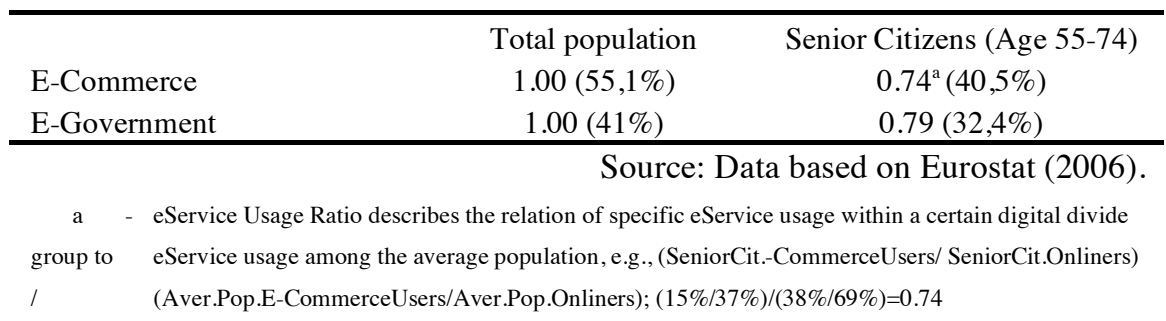

Analysing the specific reasons for non-usage in such digital divide group perspectives led to the following key findings. As for the population average, missing personal contact, concerns about data security, and the complexity of services are considered as major reasons for E-Government non-usage among digital divide groups in Germany. Concerns about data security were mentioned as reasons for non-usage of E-Government 1.27 times more often by senior citizens than by population average. The complexity of E-Government services was mentioned as a reason for non-usage 1.24 times more often by senior citizens than by population average. This leaves the four major reasons for senior citizens to not use E-Government services to be: missing personal contact, concerns about data security, service complexity, and concerns about additional costs (see Table 5).

Table 5. Reason for Not Using E-Government Services (Germany).

\begin{tabular}{lcc}
\hline & Total Population & Senior citizens (Age 55-74) \\
Service not available / too difficult to find & $1(21 \%)$ & $0.78^{\mathrm{a}}(16 \%)$ \\
Personal contact missed & $1(48 \%)$ & $1.08(52 \%)$ \\
Concerned about data security & $1(40 \%)$ & $0.93(37 \%)$ \\
Concerned about additional costs & $1(13 \%)$ & $1.27(17 \%)$ \\
Too complex & $1(24 \%)$ & $1.24(30 \%)$ \\
Other reasons & $1(16 \%)$ & $0.89(14 \%)$ \\
\hline & Source: Data based on Eurostat $(2006)$. \\
a $\quad-\quad$ Relation to population average used to highlight group specific reasons \\
ior $\quad$ E.g., 0,78 (Senior citizens, Reason: Service not available) represents $16 \%(0,78 * 21 \%=16 \%)$ of the sen-
\end{tabular}

Especially concerns about additional costs, complexity, and missing personal contact have been mentioned by senior citizens more often than by population average. Here, it might me argued that these three reasons for non-usage would in a similar way affect both E-Commerce and E-Government usage. For instance, E-Commerce might not be a desirable alternative to shopping in a physical store as personal contact is missing here as well. E-Commerce also includes services of certain complexity, e.g. auctioning for and buying an item online. Additional costs can be interpreted as costs of additional infrastructure necessary to be able to use the internet (69\% population average, $37 \%$ senior citizens) and then to use specific services such as EGovernment.

As a consequence, the data presented might be interpreted in a way that there is a smaller gap between E-Commerce and E-Government usage in the group of senior 
citizens than in the total population. It might, comparing these two eServices, not only be specific problems of E-Government which E-Government managers have to tackle when looking for creating age-aware inclusive E-Government solution. Major EGovernment problems, as the data suggests, include those which affect general internet usage (e.g., infrastructure (cost) problems) as well as usage of complex online services in general, such as E-Commerce and E-Government (e.g., complexity and the missing possibility to ask someone certain questions which may arise during service usage).

Nonetheless, we argue that at current there is still major potential left in EGovernment for including senior citizens. This could contain, for instance, senior citizen-specific design of life events or designing more one-stop-government-oriented solutions (Wimmer 2002) which are easier to access and to understand, as extensive knowledge of public administration structures and lengthy search processes for EGovernment services are not necessary. Here, potentially the EU service directive, which has to implemented in EU member states by end of 2009, could pave the road not only for a one-stop-government for businesses, but also for (senior) citizens. Here, good-practices of age-aware inclusive E-Government, for instance, 'Seniorenlotse' (www .seniorenlotse.bremen.de), 'CitizenAdvice' (www.citizensadvice.org.uk), or senior citizen portals (such as www.seniors. gov.au) could provide potentially fruitful starting points.

\section{Summary and Future Research}

From the perspective of E-Government managers, there is an uncertainty of which measures to undertake in order to increase inclusiveness of electronic public service delivery. One can identify several problem streams, issues and barriers overlapping and adding upon one another creating the current picture of prevailing E-Government exclusiveness. Regarding the perspective of senior citizens, major reasons for them for not using E-Government services are not necessarily E-Government-specific but affect general internet usage (e.g., infrastructure costs) as well as usage of (other) complex online services such as E-Commerce (e.g., complexity or missing personal contact). This reflects the fact that, in Germany, the gap between E-Commerce and EGovernment usage for senior citizens is $3 \%$ while it is $10 \%$ for the total population. Future research is necessary as the above given findings can only be regarded as a basic starting point, for instance, in terms of comprehensive qualitative and comparative studies on local age-aware E-Government.

\section{References}

Becker et. al.: "E-Inclusion - Digitale Integration durch E-Government", Münster, 2008.

Birg, H.: "Die demographische Zeitenwende. Der Bevölkerungsrückgang in Deutschland und Europa", München, 2005. 
Davis, F.D., Bagozzi, R.P. and Warshaw, P.R.: "User Acceptance of Computer Technology - A comparision of two theoretical models", Management Science Vol. 35 No. 8, August 1989, pp. 9891003 .

European Commission: "eInclusion@EU: Strengthening eInclusion \& eAccessibility across Europe. Analytic framework - eInclusion and eAccessibility priority issues", 2004a.

European Commission: "Top of the web. User Satisfaction and Usage Survey of E-Government services", Kopenhagen, 2004b.

European Commission: "Methodological manual for statistics on the Informations Society". Office for Official Publications of the European Communities, Luxembourg, 2006.

European Union: "Ministerial Declaration - Approved Unanimously on 11 June 2006", Riga, 2006.

Eurostat: "Statistics on households/individuals and the information society". Eurostat Office. 2007.

Hauser, P., and D. Duncan, D.: "The Study of Population. An Inventory and Appraisal", Chicago, 1959.

Kaufmann, F.: "Schrumpfende Gesellschaft. Vom Bevölkerungsrückgang und seinen Folgen", Frankfurt, 2005.

Kraner, S.: "Bridging the Digital Divide in E-Government.” Zürich 2004.

Morgan, S. and Hagewen, K.: "Fertility", Handbook of Population, D. Poston, and M. Micklin, New York, 2005, pp. 229-249.

Morris, M.G. and Venkatesh, V.: "Age Differences in Technology Adoption Decisions: Implications for a Changing Work Force", Personnel Psychology Vol. 53 No. 2, 2000, pp. 375-403.

Niehaves, B., Ortbach, K., Becker, J.: "The Demographic Challenge: Aging and Depopulation and their Consequences for E-Government - A Case Study”. Unpublished Manuscript. Muenster (2008)

Population Reference Bureau: "World Population Data Sheet”, Washington DC, USA, 2006.

Shirley, A.B.: "E-Government Visual Accessibility for Older Adult Users", Social Science Computer Review Vol. 22 No 1, 2004, pp. 11-23.

Wimmer, M. A.: Integrated Service Modelling for Online One-Stop Government. Electronic Markets 12 (2002) 149-156 